\title{
ガスクロマトグラフィーによる鮮魚介類並びにその加工品の 揮発性アミン及びアンモニアの定量*1
}

(昭和 58 年 10 月 26 日受理)

外海 泰 秀*2 伊藤誉志男 ${ }^{* 2}$ 原田基夫*2

\section{Determination of Volatile Amines and Ammonia in Raw Fish and Fish Products by Gas Chromatography}

\author{
Yasuhide TonogaI, Yoshio Ito and Motoo HaRAda
}

(National Institute of Hygienic Sciences, Osaka Branch: 1-1-43, Hoenzaka, Higashi-ku, Osaka, Japan)

\begin{abstract}
A separative determination method for monomethylamine, dimethylamine, trimethylamine and ammonia in raw fish and fish products was developed by head space gas chromatography. The three amines in potassium hydroxide solution (50\%) were volatilized by heating. Ammonia in acetate buffer $(\mathrm{pH} \mathrm{3.5)}$ was reacted with chloramine $\mathrm{T}$ and then heated for volatilization. The amounts of the three amines and ammonia in raw fish after various storage periods were determined, and a rapid increase of trimethylamine and ammonia was observed after $24 \mathrm{hrs}$ at room temperature. Ammonia as a percentage of total volatile compounds was in the range of $86.4 \sim 98.8 \%$ in raw fish and $48.3 \sim 93.9 \%$ in dried fish products. Total volatile compounds (A) determined by head space gas chromatography and (B) determined by Conway's method were compared. The ratios A/B ranged between 1.0 and 1.2 in raw fish and between 1.2 and 1.7 in dried fish products, i. e., the amounts found by gas chromatography were rather higher than those by Conway's method.
\end{abstract}

(Received October 26, 1983)

Key words: モノメチルアミン monomethylamine; ジメチルアミン dimethylamine; トリメチル アミン trimethylamine; アンモニア ammonia; ヘッドスペースーガスクロマトグラフィー head space gas chromatography; コンウェー法 Conway’s method; 鮮魚 raw fish

\section{緒言}

魚介類の鮮度, 腐敗度を調べる理化学的方法には, 揮 発性塩基窒素, トリメチルアミン (TMA), アンモニア などを測定する方法がある，揮発性塩基窒素の定量には コンウェーの装置を用いる 微量拡散法があり ${ }^{1)}$, TMA の定量には, 微量拡散後又は水蒸気蒸留後溶媒抽出しガ スクロマトグラフィー (GC) で定量する方法2).3などが 報告されている.

*1 食品の腐敗に関する研究（第 2 報）

*2 国立衛生試験所大阪支所：大阪市東区法円坂 1-143

*島津アプリケーションニュース No. 18
しかし微量拡散法では拡散操作に長時間を要すると共 に個々のアミン類を分別できず, 水蒸気蒸留法では操作 中の損失もあり, 通常の GCではアミンのテーリング及 び溶媒の妨害4)を防止する工夫が必要である.

またアンモニアの定量にはピリジン・ピラゾロン法 ${ }^{5)}$, インドフェノール法 ${ }^{6)}$ などの比色法や熱伝導度形検出器 TCD, 高周波誘導加熱方式 FTD による GC* がある.

しかし比色法では共存成分の影響があり，GC では測定 感度が不十分である.

著者らは魚介類の鮮度を調べるための指標として揮発 性のモノメチルアミン (MMA), ジメチルアミン

(DMA) 及び TMA を選び, さらにアンモニアを含めて 
これらを簡単・迅速に, しかも同時に定量して総合的に 鮮度の判定をする方法について検討した。

\section{実験方法}

1. 試料

鮮魚介類としてサバ，イワシ，アサリ，小エビ，加工 品として煮干し，ひらごちりめん，さきいか，干たら， 干にしん，干かわはぎ，たらこを市場より購入し用い た.

\section{2. 試薬}

MMA, DMA, TMA の塩酸塩及び塩化アンモニウム は, 和光純薬工業 (株) 製, クロラミン Tは半井化学薬品 (株)製のそれぞれ試薬特級を用いた。

MMA 標準溶液: MMA 塩酸塩 $0.676 \mathrm{~g}$ を $0.1 \mathrm{~N}$ 塩 酸に溶かして $1,000 \mathrm{ml}$ とした.この液 $1 \mathrm{ml}$ は $10 \mu$ モ ルの MMA を含む.

DMA 標準溶液：DMA 塩酸塩 $0.816 \mathrm{~g}$ を $0.1 N$ 塩 酸に溶かして $1,000 \mathrm{ml}$ とした.この液 $1 \mathrm{ml}$ は $10 \mu$ モ ルの DMA を含む.

TMA 標準溶液: TMA 塩酸塩 $0.956 \mathrm{~g}$ を $0.1 N$ 塩 酸に溶かして $1,000 \mathrm{ml}$ とした. この液 $1 \mathrm{ml}$ は $10 \mu$ モ ルの TMA を含む.

アンモニア標準溶液：塩化アンモニウム $0.535 \mathrm{~g}$ をと り, 水で $1,000 \mathrm{ml}$ とした. この液 $1 \mathrm{ml}$ は $10 \mu$ モルの アンモニアを含む.

クロラミン T溶液：クロラミン $\mathrm{T}$ 三水和物 $112.7 \mathrm{~g}$ を水 に溶かして $1,000 \mathrm{ml}$ とした. この液 $1 \mathrm{ml}$ はクロラミ ンT $400 \mu$ モルを含む.

酢酸緩衝液： $3 M$ 酢酸と $3 M$ 酢酸ナトリウム溶液で $\mathrm{pH} 3.5$ に調整した.

ホウ酸吸収剤：ホウ酸 $10 \mathrm{~g}$ を $1 \mathrm{~L}$ の共栓メスシリン ダーにとり，これにアルコール $200 \mathrm{ml}$ を加えて溶かし， さらに $0.066 \%$ メチレッド・ブロムクレゾールグリ ン混合指示薬 $10 \mathrm{ml}$ を加えて定容とした.

3. 装

ヘッドスペース用試験管：内径 $1.5 \mathrm{~cm}$, 長さ $10 \mathrm{~cm}$, 容量約 $15 \mathrm{ml}$ の試験管にシリコン製のゴムキャップを 装着した.

ガスクロマトグラフ：島津製作所 (株) 製, GC-7AG 型, 水素炎イオン化検出器及びフレームサーミオニック ディテクタ付.

カラム: Chromosorb 103 (60 80 mesh), $3.2 \mathrm{~mm} \phi$ $\times 2.6 \mathrm{~m}$.

コンウェー装置: 柴田化学 (株) 製, 微量拡散分析器, 標準ユニットを使用した.

冷却遠心機：(株) 日立製作所製，18PR-3 型

\section{4. 分析操 作}

\section{4-1 試験溶液の調製}

試料の可食部を細切し，その $10 \mathrm{~g}$ と $10 \%$ トリクロル 酢酸溶液 $40 \mathrm{ml}$ をブレンダーカップにとり, 氷冷しなが
ら 1 分間ホモジナイズし，除タンパクと抽出を行ら．氷 冷しながら 30 分間放置後， $10^{\circ}$ に設定した遠心機を用 い, $8,000 \mathrm{rpm}$ で 5 分間遠心分離し，その上澄液を分 取する. 残渣に $10 \%$ トリクロル酢酸溶液 $40 \mathrm{ml}$ を加 え, 再び同様に操作し上澄液を合わせ, $5 N$ 水酸化カリ ウム溶液で $\mathrm{pH} 5$ に調整後水で $100 \mathrm{ml}$ の定容とし試験 溶液とした。

\section{4-2 MMA, DMA, TMA の定量法}

あらかじめ $50 \%$ 水酸化カリウム溶液 $3 \mathrm{ml}$ を入れ $60^{\circ}$ に保持したヘッドスペース用試験管に, シリコン栓 を通して試験溶液 $1 \mathrm{ml}$ を注射器で入れる. 試験管を $60^{\circ}$ の水浴中で 5 分間加温した後激しく振り混ぜ, その ヘッドスペース部の気体 $1 \mathrm{ml}$ をシリコン栓を通してマ イクロシリンジで取り, ガスクロマトグラフに注入し た。

\section{4-3 アンモニアの定量法}

めらかじめ試験溶液 $1 \mathrm{ml}$ と酢酸緩衝液 $3 \mathrm{ml}$ を入れ $60^{\circ}$ に保持したヘッドスペース用試験管に，シリコン栓 を通してクロラミンT溶液 $1 \mathrm{ml}$ を注射器で入れる. 試

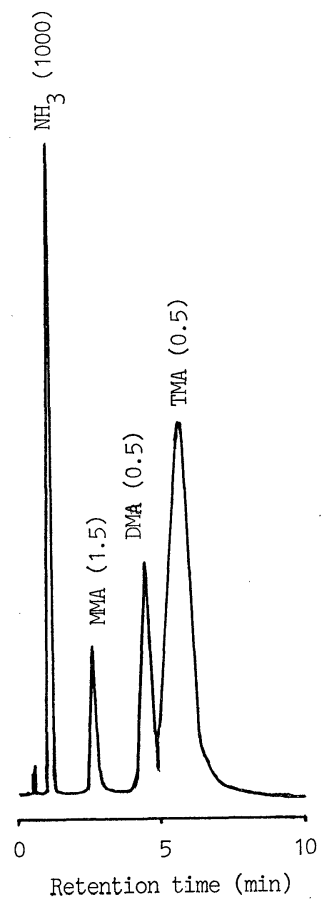

Fig. 1. Gas chromatogram of volatile amines and ammonia by head space method GC conditions, column: Chromosorb 103 $(3.2 \mathrm{~mm} \phi \times 2.6 \mathrm{~m})$

temperature: C.T. $120^{\circ} \mathrm{C}$, I.T. $220^{\circ} \mathrm{C}$ flow rate: nitrogen $25 \mathrm{ml} / \mathrm{min}$ ( ), $\mu \mathrm{mole} / \mathrm{tube}$ 

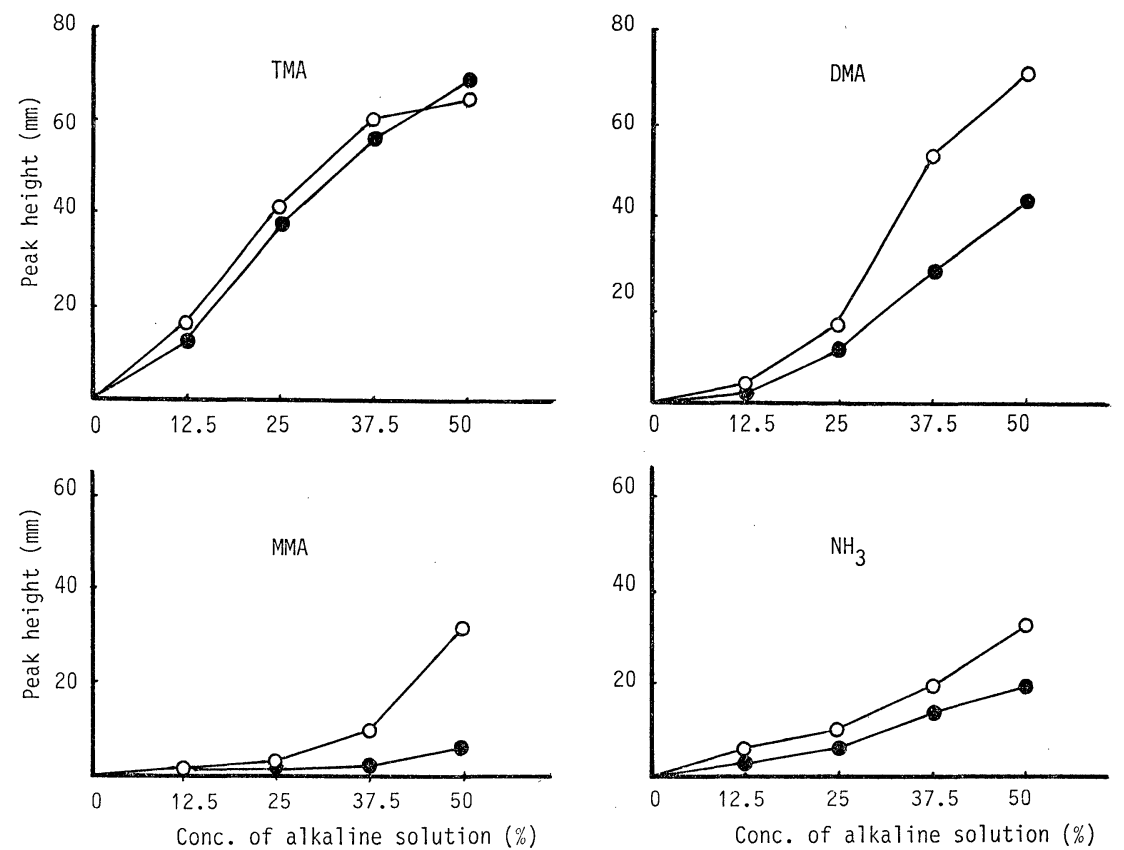

Fig. 2. Effects of alkaline media and their concentration on volatilization of TMA, DMA, MMA and $\mathrm{NH}_{3}$

- $\mathrm{O}-\mathrm{KOH}$ TMA, DMA, MMA, $10 \mu$ mole/tube GC sensitivity, $10^{-3} \times 1 / 4$

- - $\mathrm{K}_{2} \mathrm{CO}_{3} \quad \mathrm{NH}_{3}, 1,000 \mu \mathrm{mole} /$ tube Sens. $10^{-2} \times 1 / 4$

Three $\mathrm{ml}$ of alkaline solution and $1 \mathrm{ml}$ of sample solution were heated at $60^{\circ} \mathrm{C}$, $5 \mathrm{~min}$. One $\mathrm{ml}$ of the head space was injected into GC.

験管を $60^{\circ}$ の水浴中で 15 分間加温した後激しく振り混 ぜ,そのへッドスペース部の気体 $1 \mathrm{ml}$ をシリコン栓を 通してマイクロシリンジで取り, ガスクロマトグラフに 注入した。

\section{4-4 微量拡散法による揮発性塩基窒素の定量}

コンウェーニニットの内室にホウ酸吸収剤 $1 \mathrm{ml}$ を入 れ, 外室に試験溶液 $1 \mathrm{ml}$ 及び $50 \%$ 水酸化カリウム溶 液 $1 \mathrm{ml}$ を入れ，ただちにフタをして $25^{\circ} て ゙ 2$ 時間放置 した. その後内室の吸収液を $0.02 \mathrm{~N}$ 硫酸で滴定した.

\section{実験結果及び考察}

\section{MMA, DMA, TMA 及びアンモニアの GC 条件 の検討}

試料から抽出した揮発性アミン及びアンモニアを, 簡 易な操作でしかも妨害成分の影響の少ないヘッドスペー ス・GC 法で分別定量する至適条件について検討した. 各揮発性アミン及びアンモニアの標準溶液をアルカリ性 で少時加温した後, ヘッドスペース法で測定した GC チャートを Fig. 1 に示した.

アンモニアは空気ピークのすぐ後に出て感度が非常に 低いが，揮発性アミンは MMA, DMA, TMA の順に現 われ，その感度は TMA $>$ DMA > MMA の順に大さか った. その他の揮発性アミンではジェチルアミンが $\mathrm{R}_{t}$
20 分に出る程度で, $n$-プロピルアミン, $n$-ブチルアミ ンなどはいずれも $\mathrm{R}_{t}$ が大きくピークもテーリングし た。

食品の腐敗過程においては上記 3 種以外のアミンが生 成される可能性は少ないてので, 本報では MMA, DMA, TMA さらにアンモニアを定量することにし，こ れらの定量条件について検討した.

\section{MMA, DMA, TMA 及びアンモニアの気化条件の} 検討

\section{2-1 アルカリ溶液の検討}

従来コンウェー法を用いる揮発性塩基窒素の気化には $25 \%$ 水酸化カリウム溶液 ${ }^{5)}$ ， $50 \%$ 炭酸カリウム溶液 ${ }^{1)}$, 飽和炭酸カリウム溶液8)などが使用されている.

著者らは各種濃度の炭酸カリウム溶液又は水酸化カリ ウム溶液に 3 種の揮発性アミン及びアンモニアを別々に 加光, 少時加温後ヘッドスペース法でガスクロマトグラ フに注入した時のそれぞれの気化効率を比較した。

TMA では両アルカリ溶液に大差は見られないが, DMA，MMA 及びアンモニアでは水酸化カリウム溶液 の方がこれらの気化効率のよいことがわかった． 従って アルカリとしては 50\% 水酸化カリウム溶液を用いるこ とにした。なおへッドスペース用試験管に入れるアルカ 


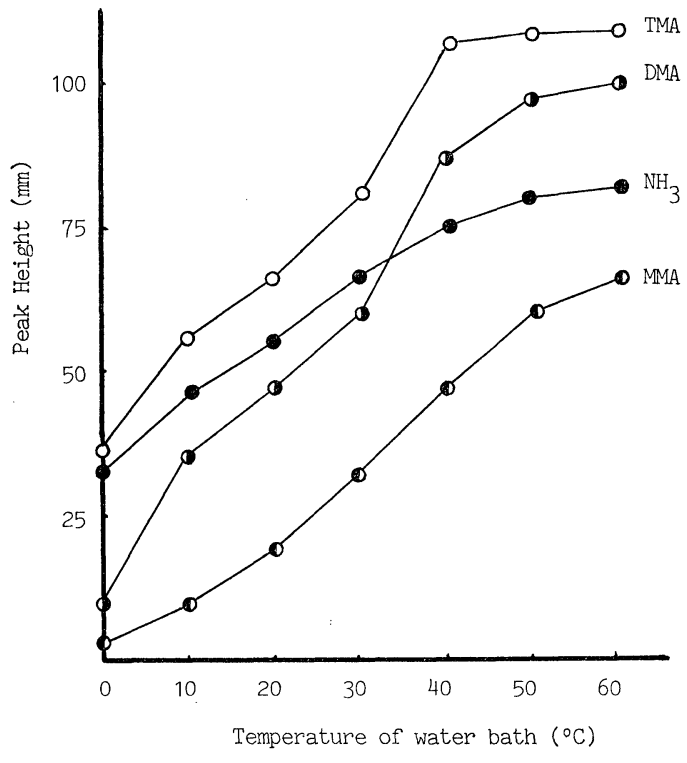

Fig. 3. Effect of temperature on volatilization of TMA, DMA, MMA and $\mathrm{NH}_{3}$

Note: Three $\mathrm{ml}$ of $50 \%$ potassium hydroxyde solution and $1 \mathrm{ml}$ of prepared solution were heated in a water bath for 10 $\min$.

リ量は, 試験溶液 $1 \mathrm{ml}$ に対して $3 \mathrm{ml}$ が適当であった。

\section{2-2 加温条件の検討}

3 種の揮発性アミン及びアンモニアの気化効率に及注 す水浴の 加温条件を検討した. 水浴温度と各化合物 の GC 上ピーク高との関係を求め, Fig. 3 亿示した.

水浴温度が高まるほど各アミン及びアンモニアのピー クは高くなったが，60 以上では内圧のため栓が飛ら゙の で加温は $60^{\circ}$ と定めた．また加温時間は 5 分で各ピーク は一定となったので, 反応液は $60^{\circ}, 5$ 分間加温するこ とにした。

\section{3. ヘッドスペース法による検量線}

今までに定めた条件での検量線をFig. 4 亿示した.

各アミンの検量線は $0.05 \sim 0.25 \mu \mathrm{mole} / \mathrm{tube}$ の範囲 で良好な直線性を示し, 湘定の繰返し精度は $8.5 \%$ 以下 であり, 検出限界は $0.1 \mu \mathrm{mole} / \mathrm{sample}(\mathrm{g})$ であった. またアンモニアについての検量線範囲は $200 \sim 1,000 \mu$ mole/tube となり，感度は上記のアミン類に比し極めて 低いことがわかった。

一方, 窒素に特異的な感度を示す FTD-GC を使用し て3 種のアミンを測定すると感度は約 100 200 倍高く なった。しかし FTD-GC でもアンモニアの感度は依然 として低く, 試料から定量するには何らかの方法で測定 感度を上げる必要があった。

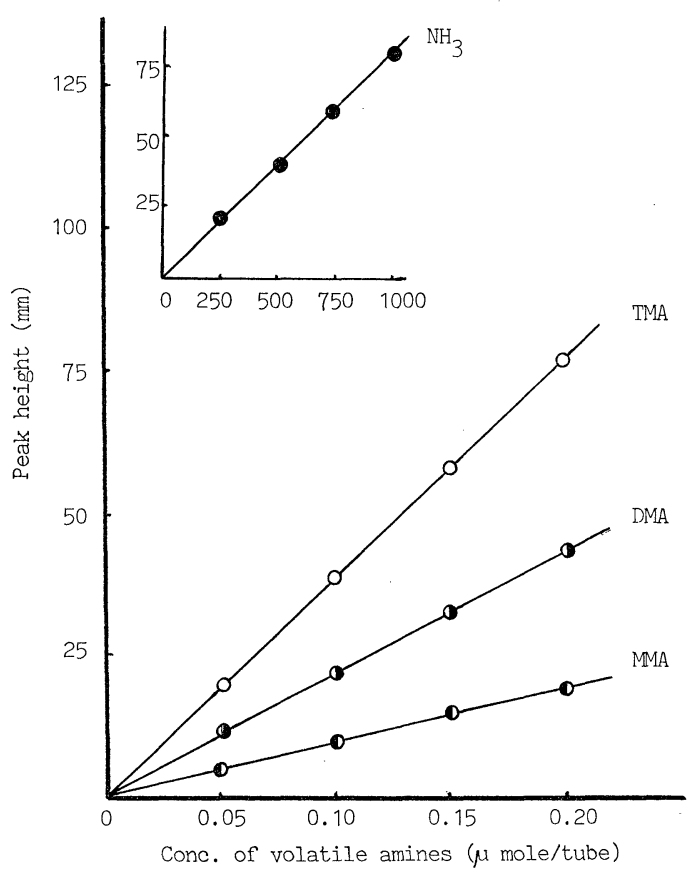

Fig. 4. Calibration curves of TMA, DMA, MMA and $\mathrm{NH}_{3}$ determined by head space method

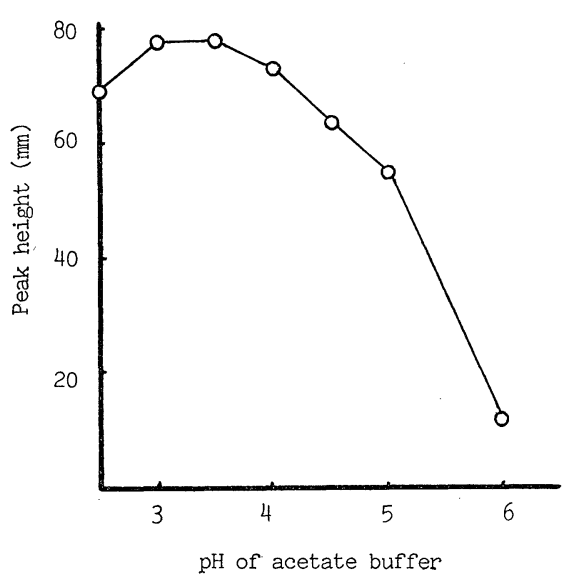

Fig. 5. Effect of pH of acetate buffer on formation of the compound from ammonia treated with chloramine $\mathrm{T}$

Note: Three $\mathrm{ml}$ of acetate buffer, $1 \mathrm{ml}$ of ammonia solution ( $10 \mu \mathrm{mole} /$ tube $)$ and $1 \mathrm{ml}$ of $1 \%$ chloramine $\mathrm{T}$ solution were mixed and heated at $60^{\circ} \mathrm{C}, 10 \mathrm{~min}$.

\section{4. アンモニア誘導体の生成}

アンモニアの比色定量法に和いて畧本らは5), アンモ 


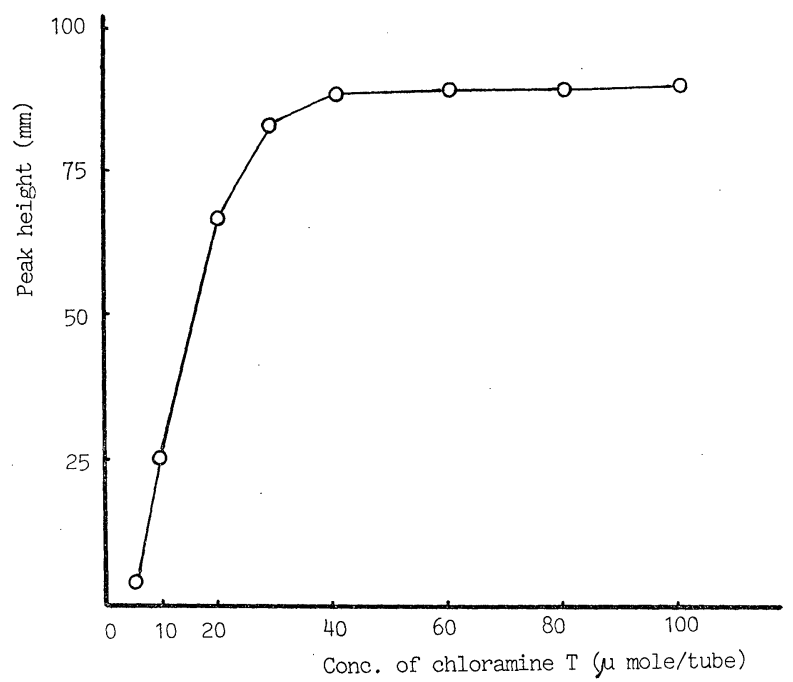

Fig. 6. Effect of conc. of chloramine $T$ on formation of the compound from ammonia

Note: Concentration of ammonia is $10 \mu \mathrm{mole} /$ tube.

ニアとクロラミンTの反応物を四塩化炭素で抽出し, ビ スピラゾロンと反応させ 比色定量している．また田中 ら*はシアンをクロラミンTと反応させ，へッドスペー ス法でクロルシアンを感度よく測定している.

著者らは㑼本らの原理に従ってアンモニアにクロラミ ンTを加熱下で反応させ，その反応物を直接へッドスペ 一ス法で定量することを試み，その測定至適条件を検討 した.

アンモニアを各種 $\mathrm{pH}(2.5 \sim 6.0)$ の酩酸緩衝液と混 和し，さらにクロラミンTを作用させ試験管内のへッド スペースをガスクロマトグラフに注入し，ピーク高と $\mathrm{pH}$ との関係を調べたところ，Fig. 5 に示したように反 応液の $\mathrm{pH}$ が 3.0〜3.5 でピークは最高となった。 また 試験溶液 $1 \mathrm{ml}$ 亿対して酢酸緩衝液の濃度は $3 \mathrm{M}$, 炎の 容量は $3 \mathrm{ml}$ が適当であった。な打酢酸以外の緩衝液を 用いても，アンモニア誘導体のピークはガスクロマトグ ラムに現われなかった。

次にアンモニアとクロラミンTの反応に持ける両者の 量的関係を調べた。 アンモニア $10 \mu \mathrm{mole} / \mathrm{tube}$ に対し てクロラミンT量を変化させた時のガスクロマトグラム のピーク高を比較し, Fig. 6 亿示した.

クロラミンT濃度が $30 \mu \mathrm{mole} / \mathrm{tube}$ 以上でピーク高 は一定となった。すなわちアンモニア 1 mole に対して クロラミンTは 3 mole 反応するものと考光られ, 従っ て生成する化合物はアンモニアのトリクロル置換体であ ろらと推察された。な特生成物の気化効率に及ぼす水浴 の加温条件は, 温度を高めるほど GC 上のピークは高く

* 田中康夫, 木川寛, 河村太郎：日本食品衛生学会第 34 回学術講演会要旨集, p. 32

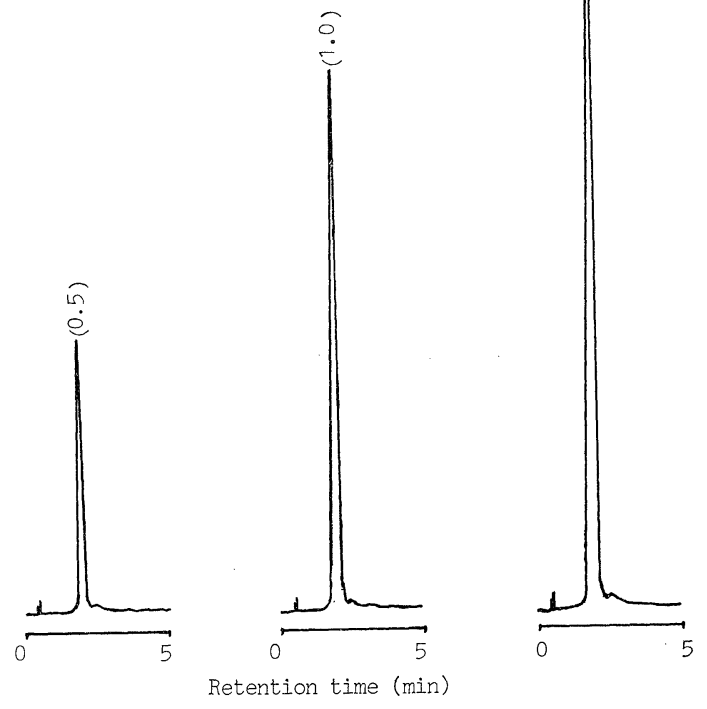

Fig. 7. Gas chromatogram of ammonia treated with chloramine $\mathrm{T}$ by head space method GC condition, column: Chromosorb 103 $(3.2 \mathrm{~mm} \emptyset \times 2.6 \mathrm{~m})$ temperature: C.T. $120^{\circ} \mathrm{C}$, I.T. $220^{\circ} \mathrm{C}$, flow rate: nitrogen $25 \mathrm{ml} / \mathrm{min}$ ( ), $\mu$ mole/tube 
Table 1. Recoveries of TMA, DMA, MMA and $\mathrm{NH}_{3}$ from Raw Marine Foods

\begin{tabular}{|c|c|c|c|c|}
\hline \multirow{2}{*}{ Compound } & \multirow{2}{*}{$\begin{array}{l}\text { Added } \mu \text { mole/ } \\
\text { sample }(\mathrm{g})\end{array}$} & \multicolumn{3}{|c|}{ Found: $\mu$ mole/sample (g) (Recovery*\%) } \\
\hline & & Mackerel & "Asari" & Shrimp \\
\hline \multirow[t]{2}{*}{ TMA } & 0 & 0.15 & 0.18 & 0.10 \\
\hline & 1.0 & $\begin{array}{c}1.13 \\
(98.0)\end{array}$ & $\begin{array}{c}1.15 \\
(97.4)\end{array}$ & $\begin{array}{c}1.08 \\
(98.5)\end{array}$ \\
\hline \multirow[t]{2}{*}{ DMA } & 0 & 0 & 0 & 0 \\
\hline & 1.0 & $\begin{array}{c}0.92 \\
(92.0)\end{array}$ & $\begin{array}{c}0.93 \\
(93.0)\end{array}$ & $\begin{array}{c}0.93 \\
(93.0)\end{array}$ \\
\hline \multirow[t]{2}{*}{ MMA } & 0 & 0 & 0 & 0 \\
\hline & 2.5 & $\begin{array}{c}2.35 \\
(94.0)\end{array}$ & $\begin{array}{c}2.32 \\
(92.8)\end{array}$ & $\begin{array}{c}2.34 \\
(93.6)\end{array}$ \\
\hline \multirow{3}{*}{$\mathrm{NH}_{3} * *$} & 0 & 8.9 & 5.0 & 6.5 \\
\hline & 10.0 & $\begin{array}{c}18.1 \\
(92.0)\end{array}$ & $\begin{array}{c}14.4 \\
(94.0)\end{array}$ & $\begin{array}{c}16.8 \\
(93.0)\end{array}$ \\
\hline & 100.0 & $\begin{array}{l}104.9 \\
(96.0)\end{array}$ & $\begin{array}{l}100.6 \\
(95.6)\end{array}$ & $\begin{array}{l}101.8 \\
(95.3)\end{array}$ \\
\hline
\end{tabular}

* average of three trials

** Ammonia treated with chloramine $\mathrm{T}$

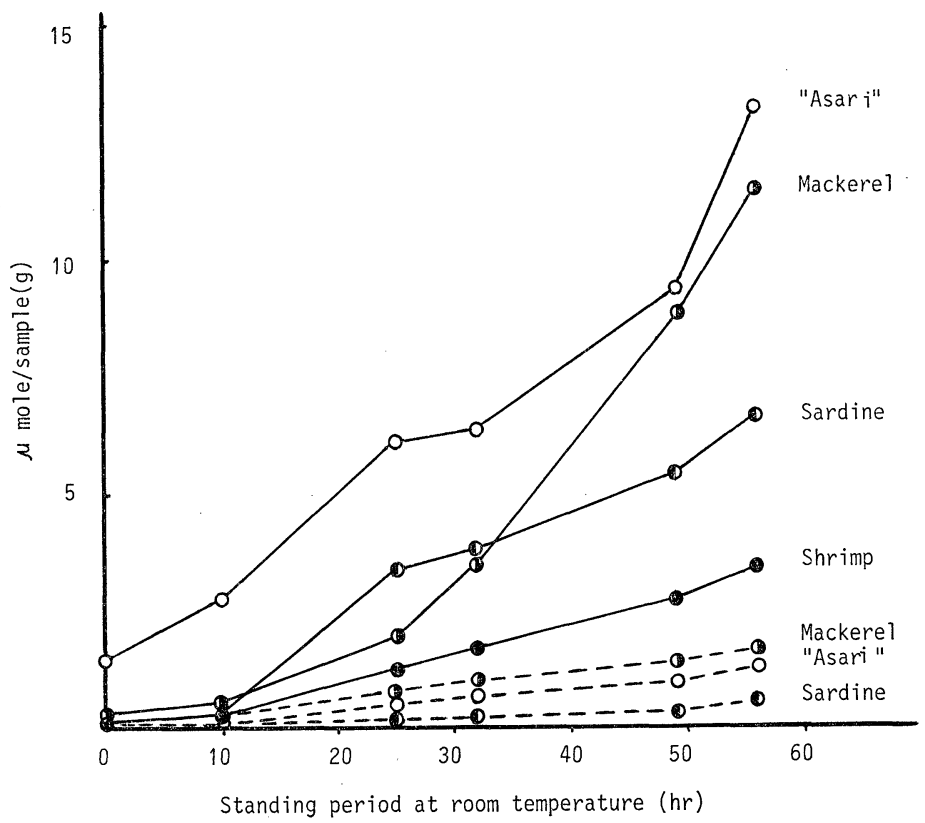

Fig. 8. Time course for the formation of TMA, DMA and MMA in raw marine foods - -, TMA --- $\bigcirc-\cdot$, MMA

なった.しかし $60^{\circ}$ 以上では試験管内圧のためシリコン 栓が飛ぶので, 加温は $60^{\circ}$ とした. 加温時間は15分で十 分であった.

\section{5. アンモニア誘導体の GC}

クロラミンT処理したアンモニアの $\mathrm{GC}$ チャートを Fig. 7 に示した.

ピークは再現性よく単一のピークとして現われ，この
ピーク高はアンモニア濃度に比例した。.また他の揮発性 アミンを同様にクロラミンT処理してもこのピークは現 われず，アンモニアに特異的なピークであった.

FID-GC によるアンモニア誘導体の検量線は 0.25 $1.00 \mu \mathrm{mole} / \mathrm{tube}$ の範囲で良好な直線性を示し, 繰返し 測定精度は $7.6 \%$ 以下であり, 検出限界は $0.05 \mu$ mole/sample (g) であった。 


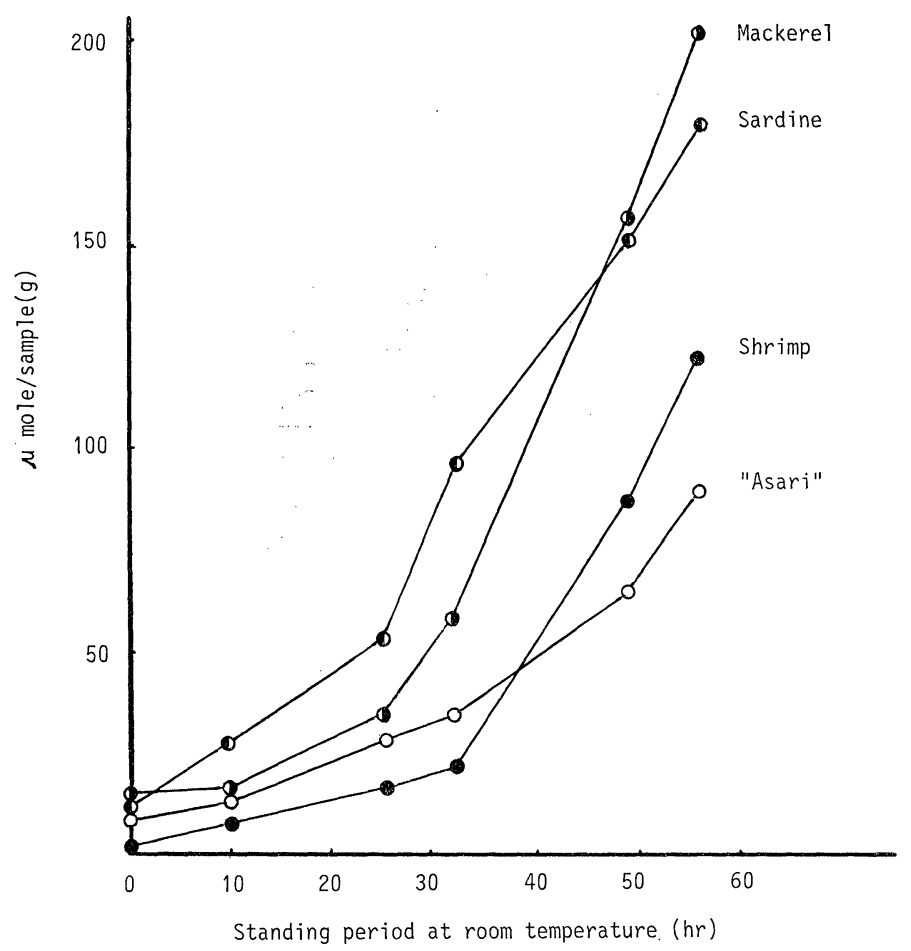

Fig. 9. Time course for the formation of ammonia in raw marine foods

Table 2. Contents of MMA, DMA, TMA and $\mathrm{NH}_{3}$ in Raw Marine Foods Determined by Head Space GC Method and Conway's Method

\begin{tabular}{|c|c|c|c|c|c|c|c|c|}
\hline \multirow{2}{*}{ Raw marine food } & \multirow{2}{*}{$\mathrm{hr}$} & \multicolumn{5}{|c|}{ Head space GC method } & \multirow{2}{*}{$\begin{array}{l}\text { Conway's } \\
\text { method (B) }\end{array}$} & \multirow{2}{*}{$\begin{array}{l}\text { Ratio } \\
(\mathrm{A} / \mathrm{B})\end{array}$} \\
\hline & & MMA & DMA & TMA & $\mathrm{NH}_{3}$ & Total & & \\
\hline \multirow[t]{2}{*}{ Mackerel "saba" } & 0 & $\begin{array}{r}\text { N D } \\
(0)\end{array}$ & $\begin{array}{l}\text { N D } \\
(0)\end{array}$ & $\begin{array}{c}0.38 \\
(1.9)\end{array}$ & $\begin{array}{c}19.68 \\
(98.1)\end{array}$ & $\begin{array}{c}20.26 \\
(100.0)\end{array}$ & 16.8 & 1.19 \\
\hline & 50 & $\begin{array}{l}1.75 \\
(0.8)\end{array}$ & $\begin{array}{l}\mathrm{N} \mathrm{D} \\
(0)\end{array}$ & $\begin{array}{l}10.89 \\
(5.3)\end{array}$ & $\begin{array}{l}194.34 \\
(93.9)\end{array}$ & $\begin{array}{c}206.98 \\
(100.0)\end{array}$ & 181.6 & 1.14 \\
\hline \multirow[t]{2}{*}{ Sardine "iwashi" } & 0 & $\begin{array}{r}\mathrm{ND} \\
(0)\end{array}$ & $\begin{array}{l}\text { N D } \\
(0)\end{array}$ & $\begin{array}{l}0.18 \\
(1.2)\end{array}$ & $\begin{array}{c}14.64 \\
(98.8)\end{array}$ & $\begin{array}{c}14.82 \\
(100.0)\end{array}$ & 14.5 & 1.02 \\
\hline & 50 & $\begin{array}{c}0.44 \\
(0.2)\end{array}$ & $\begin{array}{l}\text { N D } \\
(0)\end{array}$ & $\begin{array}{l}6.69 \\
(3.4)\end{array}$ & $\begin{array}{c}186.96 \\
(96.4)\end{array}$ & $\begin{array}{c}194.09 \\
(100.0)\end{array}$ & 153.2 & 1.27 \\
\hline \multirow[t]{2}{*}{ Shellfish "asari" } & 0 & $\begin{array}{l}\text { N D } \\
(0)\end{array}$ & $\begin{array}{l}\text { N D } \\
(0)\end{array}$ & $\begin{array}{r}1.83 \\
(12.8)\end{array}$ & $\begin{array}{c}12.42 \\
(87.2)\end{array}$ & $\begin{array}{c}14.25 \\
(100.0)\end{array}$ & 14.0 & 1.02 \\
\hline & 50 & $\begin{array}{l}1.19 \\
(1.3)\end{array}$ & $\begin{array}{l}\text { N D } \\
(0)\end{array}$ & $\begin{array}{c}11.50 \\
(12.3)\end{array}$ & $\begin{array}{c}80.69 \\
(86.4)\end{array}$ & $\begin{array}{c}93.38 \\
(100.0)\end{array}$ & 75.6 & 1.23 \\
\hline \multirow[t]{2}{*}{ Shrimp "koebi" } & 0 & $\begin{array}{l}\text { N D } \\
(0)\end{array}$ & $\begin{array}{l}\text { N D } \\
(0)\end{array}$ & $\begin{array}{c}0.22 \\
(3.5)\end{array}$ & $\begin{array}{c}6.15 \\
(96.5)\end{array}$ & $\begin{array}{r}6.37 \\
(100.0)\end{array}$ & 5.8 & 1.10 \\
\hline & 50 & $\begin{array}{c}0.18 \\
(0.2)\end{array}$ & $\begin{array}{l}\text { N D } \\
(0)\end{array}$ & $\begin{array}{c}3.49 \\
(3.1)\end{array}$ & $\begin{array}{c}108.61 \\
(96.7)\end{array}$ & $\begin{array}{c}112.28 \\
(100.0)\end{array}$ & 101.4 & 1.11 \\
\hline
\end{tabular}

$\mathrm{ND}:$ less than $0.01 \mathrm{~N}-\mathrm{mg} \% /$ sample $(\mathrm{g})$ unit: $\mathrm{N}-\mathrm{mg} \%$ ( ) : percentage

6. 添加回収

3 種類の鮮魚介類に TMA, DMA, MMA 及びアン モニアを添加した時の回収率を Table 1 に示した.
サバ，アサリ，エビにおいて，四者の回収率はいずれ も $92.0 \%$ 以上と良好であった。 
Table 3. Contents of MMA, DMA, TMA and $\mathrm{NH}_{3}$ in Dried Marine Foods Determined by Head Space GC Method and Conway's Method

\begin{tabular}{|c|c|c|c|c|c|c|c|}
\hline \multirow{2}{*}{ Dried marine food } & \multicolumn{5}{|c|}{ Head space GC method } & \multirow{2}{*}{$\begin{array}{l}\text { Conway's } \\
\text { method(B) }\end{array}$} & \multirow{2}{*}{$\begin{array}{l}\text { Ratio } \\
\text { (A/B) }\end{array}$} \\
\hline & MMA & DMA & TMA & $\mathrm{NH}_{3}$ & Total (A) & & \\
\hline Dried small sardine "niboshi" & $\begin{array}{l}1.08 \\
(2.3)\end{array}$ & $\begin{array}{c}0.56 \\
(1.2)\end{array}$ & $\begin{array}{l}1.21 \\
(2.6)\end{array}$ & $\begin{array}{r}44.05 \\
(93.9)\end{array}$ & $\begin{array}{r}46.90 \\
(100.0)\end{array}$ & 36.7 & 1.23 \\
\hline Dried laval fish "hirago" & $\begin{array}{l}1.97 \\
(3.7)\end{array}$ & $\begin{array}{l}1.06 \\
(2.0)\end{array}$ & $\begin{array}{l}1.49 \\
(2.8)\end{array}$ & $\begin{array}{c}48.02 \\
(91.5)\end{array}$ & $\begin{array}{c}52.54 \\
(100.0)\end{array}$ & 38.4 & 1.37 \\
\hline Dried cuttlefish "sakiika" & $\begin{array}{l}7.02 \\
(9.4)\end{array}$ & $\begin{array}{c}13.53 \\
(18.2)\end{array}$ & $\begin{array}{l}1.63 \\
(2.2)\end{array}$ & $\begin{array}{c}52.22 \\
(70.2)\end{array}$ & $\begin{array}{r}74.40 \\
(100.0)\end{array}$ & 50.8 & 1.46 \\
\hline Dried codfish "hidara" & $\begin{array}{c}24.60 \\
(27.1)\end{array}$ & $\begin{array}{l}6.40 \\
(7.1)\end{array}$ & $\begin{array}{l}15.89 \\
(17.5)\end{array}$ & $\begin{array}{r}43.81 \\
(48.3)\end{array}$ & $\begin{array}{r}90.70 \\
(100.0)\end{array}$ & 64.4 & 1.41 \\
\hline Dried herring "Hoshi-nishin" & $\begin{array}{c}5.26 \\
(6.5)\end{array}$ & $\begin{array}{l}3.94 \\
(4.9)\end{array}$ & $\begin{array}{r}8.49 \\
(10.5)\end{array}$ & $\begin{array}{c}63.18 \\
(78.1)\end{array}$ & $\begin{array}{r}80.87 \\
(100.0)\end{array}$ & 47.6 & 1.70 \\
\hline Dried file fish "Hoshi-kawahagi" & $\begin{array}{r}12.30 \\
(13.1)\end{array}$ & $\begin{array}{c}25.34 \\
(27.0)\end{array}$ & $\begin{array}{l}7.40 \\
(7.9)\end{array}$ & $\begin{array}{r}48.87 \\
(52.0)\end{array}$ & $\begin{array}{r}93.91 \\
(100.0)\end{array}$ & 61.6 & 1.52 \\
\hline Cod roes "tarako" & $\begin{array}{r}5.90 \\
(11.6)\end{array}$ & $\begin{array}{c}4.02 \\
(7.9)\end{array}$ & $\begin{array}{l}1.32 \\
(2.6)\end{array}$ & $\begin{array}{r}39.59 \\
(77.9)\end{array}$ & $\begin{array}{r}50.83 \\
(100.0)\end{array}$ & 39.2 & 1.30 \\
\hline
\end{tabular}

unit, $\mathrm{N}-\mathrm{mg} \%$ ( ), percentage

\section{7. 試料分析}

\section{7-1 鮮魚介類中の揮発性アミン及びアンモニア量の} 経時変化

サバ，イワシ，アサリ，エビを $25^{\circ}$ で56時間放置し， 経時的な MMA, DMA, TMA 及びアンモニアの含有 量を調べ，それぞれ Fig. 8 及び 9 に示した.

TMA の生成量は 24 時間経過したあたりから急激に 増加し，56時間後の生成量は特にアサリに多く見られ $13.40 \mu \mathrm{mole} / \mathrm{g}$ すなわち $790 \mathrm{ppm}$, ついでサバ 680 ppm, イワシ 383 ppm, エビ $206 \mathrm{ppm}$ の順であった.

MMA はいずれも少なくサバで $1.64 \mu \mathrm{mole} / \mathrm{g}$ (52 $\mathrm{ppm}$ ) 程度であった. DMA は本条件下でいずれる検出 されなかった。

一方，アンモニアの生成量は24時間経過したあたりか ら急激に増加し，56 時間でサバ $203.7 \mu \mathrm{mole} / \mathrm{g}$ (3, 463 $\mathrm{ppm})$, イワシ $3,068 \mathrm{ppm}$, エビ $1,955 \mathrm{ppm}$ ，アサリ $1,535 \mathrm{ppm}$ となった. これらの值は先の揮発性アミン 量に比べると極めて多いことがわかる.

\section{7-2 本法とコンウェー法の比較}

試料中の MMA, DMA, TMA 及びアンモニアの本 法による測定值を $\mathrm{N}-\mathrm{mg} \%$ に換算し，同一試料につい てコンウェー法で測定した值と比較した. 生魚介類及び その加工品についての結果をそれぞれ Table 2 と 3 に 示した.

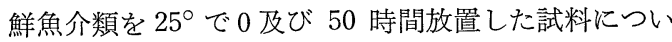
て， GC で 4 種のものを分別定量したときアンモニアの 全体に占める 割合は非常に高く，アサリでは 86〜 87\% であるが他のものでは 93〜98\%をを占めた．また GC の total 量とコンウェー法の揮発性塩基窒素量の比をとる
と, いずれも 1.0 1.2 でやや GC が高い傾向を示した が両者はほぼ一致した值を示すことがわかった.

一方，魚加工品を両法で測定した結果，いずれも揮発 性アミンの生成量が多く見られ，従ってアンモニアの全 体に占める割合は低いものが多かった．特に干たらでは MMA $27.1 \%$, DMA $7.1 \%$, TMA $17.5 \%$, アンモニ ア $48.3 \%$ であった.

また GC の total 量とコンウェー法の值の比は 1. 2〜1.7 と Table 2 の鮮魚類の場合よりも高い值を示 した. もっとも GC では反応液を $60^{\circ}$ で 5 分間加温する のに対し，コンウェー法では室温で 2 時間放置という反 応条件の相違もあるが, Table 2 と比較すると揮発性ア ミンを多く含む試料ではコンウェー法の值の低く出る傾 向が認められた.

な打今後は本法と細菌試験を比較して総合的に鮮度を 判定する方法を検討すると共に，腐敗現象の解明も行い たいと考えている.

総括

1. MMA, DMA 及び TMA を $50 \%$ 水酸化カリウ ム溶液中で気化し，ヘッドスペース・GC で定量する測 定条件を設定した。

2. アンモニアを酢酸緩衝液（pH 3.5）中でクロラミ ン $\mathrm{T}$ 反応させ，生成物を加熱しへッドスペース・GC で定量する方法を開発した．本法はアンモニアを直接定 量する方法に比し，感度を約 1,000 倍高めることができ た.

3. 鮮魚介類中の 3 種の揮発性アミン及びアンモ二 アの $25^{\circ}$ における経時的な生成量を分別定量した結果, 24 時間目あたりからアンモニア及び TMA の生成量は 
急激に増加し，アンモニア量は全体の $86.4 \sim 98.8 \%$ を 占めることがわかった.

4. 本法で定量した 鮮魚介類及び 魚加工品中の 3 種 の揮発性アミン及びアンモニアの総量をコンウェー法の 值と比較した結果, 鮮魚介類では両測定値はほぼ一致し たが, 揮発性アミンの比較的多く検出された魚加工品で はコンウェー法の方が低く出る傾向が見られた.

\section{文献}

1)厚生省環境衛生局監修: “食品衛生検查指針 (II)” p. 204 213 (1978) 日本食品衛生協会.

2) 内山貞夫, 近藤竜雄, 内山 充: 食衛誌. 17 , 345 351 (1976).
3) Gruger, E. H. Jr.: J. Agric. Food Chem., 20, 781 785 (1972).

4) 馬場二夫, 斉藤 銥, 福井弥生, 谷口 繁, 大和 田国夫，水谷泰久：食衛誌. 19, 530 535 (1978).

5) 崓本 力, 津田 穣, 林 誠: 薬誌. 80, 1, 089 1, 092 (1960).

6) 日本薬学会編：“衛生試験法・注解” p. 1,083 1, 084 (1980) 金原出版.

7）林 誠：食衛誌. 11, 429～438 (1970).

8）日本薬学会編：“衛生試験法・注解” p. 163 164 (1980) 金原出版. 